\title{
PENGARUH VARIASI PH TERHADAP SIFAT OPTIK ZNO NANOPARTIKEL DARI HASIL BIOSINTESIS
}

\author{
Devi Anggraheni ${ }^{1, a)}$, Isnaeni ${ }^{2, a)}$, Iwan Sugihartono ${ }^{1, b)}$ \\ ${ }^{1}$ Program Studi Fisika, FMIPA Universitas Negeri Jakarta, Jl. Rawamangun Muka No. O1, Rawamangun \\ 13220, Indonesia \\ ${ }^{2}$ Research Center for Physics, Indonesian Institute of Sciences, Banten 15314, \\ Indonesia \\ Email: a)devianggraheni@gmail.com, ${ }^{\text {b) }}$ iwan-sugihartono@unj.ac.id
}

\begin{abstract}
Abstrak
Berdasarkan hasil review, ZnO NPs dapat dihasilkan dari teknik biosintesis. Sifat optik (absorbansi) dipengaruhi oleh $\mathrm{pH}$ larutan zinc nitrate. Perbandingan pengaruh variasi $\mathrm{pH}$ dari teknik biosintesis dipelajari dari hasil eksperimen yang dilaporkan oleh tiga penulis yaitu Nagarajan dkk (2013) dengan variasi pH 5 sampai 10, Hoseinpour dkk (2017) dengan variasi pH 4, 6, dan 8, serta Jamdagni dkk (2016) dengan variasi pH 9 sampai 13. Berdasarkan hasil uji UV-Vis yang telah dilakukan oleh seluruh penulis, ditemukan bahwa pada $\mathrm{pH}$ yang lebih tinggi akan menyebabkan tingkat reduksi semakin tinggi, sehingga puncak penyerapan akan semakin tinggi pula. Namun, absorbansi dan ketajaman puncak akan melemah setelah mencapai $\mathrm{pH}$ tertentu. Hal tersebut memberikan informasi bahwa terdapat $\mathrm{pH}$ tertentu dimana ZnO NPs akan mencapai puncak absorbansi maksimum. Berdasarkan penelitian yang dilakukan Nagarajan dkk (2013), Hoseinpour dkk (2017), serta Jamdagni dkk (2016), pH optimum untuk mensintesis $\mathrm{ZnO}$ nanopartikel adalah 8.
\end{abstract}

Kata Kunci: Nanopartikel ZnO, Biosintesis, pH, UV-Vis, Absorbansi

\begin{abstract}
Based on paper review, ZnO NPs can be produced from biosynthetic techniques. Optical properties (absorbance) are affected by the $\mathrm{pH}$ of the zinc nitrate solution. Comparison of the effect of $\mathrm{pH}$ variations on biosynthetic techniques was studied from experimental results reported by three authors, Nagarajan et al (2013) with variations in pH 5 to 10, Hoseinpour et al (2017) with variations in pH 4, 6, and 8, and Jamdagni et al (2016) with variations in $\mathrm{pH} 9$ to 13. Based on the results of the UV-Vis test that has been done by all authors, it was found that at a higher $\mathrm{pH}$ will cause a higher level of reduction, so that the peak of absorption will be higher too. However, the absorbance and sharpness of the peak will weaken after reaching a certain $\mathrm{pH}$. This gives information that there is a certain $\mathrm{pH}$ at which $\mathrm{ZnO}$ NPs will reach their maximum absorbance peak. Based on research conducted by Nagarajan et al (2013), Hoseinpour et al (2017), and Jamdagni et al (2016), the optimum $\mathrm{pH}$ for synthesizing $\mathrm{ZnO}$ nanoparticles is 8 .
\end{abstract}

Keywords: ZnO Nanoparticles, Biosynthesis, pH, UV-Vis, Absorbance 


\section{PENDAHULUAN}

Nanopartikel (NP) adalah bahan partikel dengan setidaknya satu dimensi berada dalam skala nano $(1-100 \mathrm{~nm})$ [1]. Nanopartikel memiliki sifat yang unik, seperti ukuran berdimensi nano, rasio antara luas permukaan dan volumenya tinggi, sifat fisik dan sifat kimia spesifik [1]. Nanopartikel logam oksida telah banyak digunakan untuk tujuan pengobatan dalam beberapa dekade terakhir. Nanopartikel logam oksida juga memiliki potensi untuk diaplikasikan di lingkungan karena dapat bertindak sebagai katalis yang membantu dalam pengurangan atau penghapusan bahan kimia berbahaya dari lingkungan [2]. Selain itu, nanopartikel saat ini banyak digunakan di industri elektronik dan industri rekayasa jaringan. Nanopartikel memiliki sifat fisik dan kimia yang bergantung pada ukuran nano nya, yang tidak mungkin dilakukan pada keadaan besar [3]. Diantara logam oksida lainnya, $\mathrm{ZnO} \mathrm{NP}$ sangat diminati karena harganya murah, aman, dan bisa dibuat dengan mudah [4].

$\mathrm{ZnO}$ adalah semikonduktor logam oksida tipe-n yang banyak dikembangkan dan diminati sebagai nanomaterial luminisens karena memiliki sifat unik, yaitu memiliki celah pita langsung dari kelompok semikonduktor II-VI [5]. ZnO memiliki celah pita 3,37 eV, dengan energi eksiton ikatannya sebesar $60 \mathrm{meV}$. Tingginya energi eksiton ikatan nanopartikel $\mathrm{ZnO}$ memungkinkan eksiton efisien dalam suhu kamar [5]. ZnO merupakan zat padat berupa serbuk heksagon/amorf berwarna putih jika dingin, dan berwarna kuning jika panas, rasanya pahit dan tidak memiliki bau. Oksida amfoter ini sulit larut dalam alkohol atau air, tapi dapat larut dalam garam-garam ammonium, asam atau basa dan tidak beracun [6]. ZnO telah diselidiki secara luas selama dekade terakhir di bidang ilmu material, bioteknologi, dan teknik medis karena potensi mereka untuk diaplikasikan sebagai katalis dan penyerap bahan kimia [3].

Nanopartikel ZnO sebelumnya telah disintesis menggunakan berbagai teknik fisika dan teknik kimia, namun kedua metode tersebut memiliki kelemahan, di antaranya memerlukan peralatan mahal, dilakukan dengan suhu tinggi, menggunakan bahan-bahan kimia beracun yang limbahnya berpotensi menjadi polutan bagi lingkungan. Saat ini metode biosintesis atau green synthesis sedang dikembangkan sebagai alternatif pembuatan nanopartikel yang bersifat ramah lingkungan dan tetap menghasilkan nanopartikel dengan karakteristik yang baik [6]. Nanopartikel yang diproduksi oleh tanaman lebih stabil dan lebih bervariasi dalam bentuk dan ukuran dibandingkan dengan yang diproduksi oleh organisme lain [7].

Secara khusus, pemanfaatan ekstrak tanaman obat sebagai agen pereduksi dan stabilator yang potensial untuk sintesis struktur nano $\mathrm{ZnO}$ mencapai banyak keuntungan dibandingkan metode fisik dan kimia konvensional. Beberapa tanaman baru-baru ini telah berhasil digunakan secara efisien untuk sintesis $\mathrm{ZnO}$ NP [7]. Pada paper ini akan dibahas beberapa penelitian yang memproduksi $\mathrm{ZnO}$ NPs menggunakan tanaman.

\section{METODE PENELITIAN}

Sintesis ZnO NPs menggunakan bahan-bahan ramah lingkungan telah berhasil dilakukan oleh Nagarajan dkk (2013). Rumput Laut (Sargassum myriocystum) yang terkumpul dicuci bersih menggunakan air suling, diiris kecil-kecil dan dikeringkan pada temperatur ruang. $10 \mathrm{~g}$ rumput laut dan $100 \mathrm{ml}$ air suling dicampur dengan baik dan direbus selama 25 menit. Campuran disaring menggunakan kertas saring Whatman No.1 dan filtratnya disimpan dalam lemari es pada suhu $4{ }^{\circ} \mathrm{C}$ untuk penggunaan lebih lanjut. Ekstrak rumput laut sebanyak $5 \mathrm{ml}$ ditambahkan ke dalam $95 \mathrm{ml}$ larutan seng nitrat $1 \mathrm{mM}$. Kemudian larutan diaduk secara konstan menggunakan pengaduk magnetik untuk melarutkan seng nitrat. Setelah larut, larutan dipanaskan pada suhu $80^{\circ} \mathrm{C}$ selama 5-10 menit. PH diatur antara 5 dan 10 menggunakan larutan $0,1 \mathrm{M} \mathrm{HCl}$ atau $0,1 \mathrm{M} \mathrm{NaOH}$ dan ditempatkan pada pengaduk magnet selama 1 jam [9].

ZnO NPs juga telah berhasil disintesis menggunakan Daun Stinkwort (Dittrichia graveolens). Bubuk Daun Stinkwort sebanyak $8 \mathrm{~g}$ dicampur dengan $200 \mathrm{ml}$ air suling dan di rebus selama 5 menit. Campuran didinginkan dan disentrifugasi pada 3500 rpm selama 10 menit. Supernatan disimpan pada suhu $4{ }^{\circ} \mathrm{C} .1 \mathrm{mM}$ larutan seng nitrat pada $\mathrm{pH}$ yang berbeda $(4,6$ dan 8$)$ dicampur dengan beberapa rasio ekstrak daun (75:25 dan 25:75) dalam berbagai waktu (40,80 dan 120 menit) dan diaduk pada 
suhu kamar. Endapan didapatkan dengan sentrifugasi, dicuci dengan air deionisasi dan etanol untuk beberapa kali, dan didiamkan dalam $7 \mathrm{ml}$ air suling [10].

Selain itu, ZnO NPs juga telah berhasil disintesis menggunakan Biji Jintan Putih (Cuminum cyminum). Biji jinten sebanyak $20 \mathrm{~g}$ dibersihkan dari debu dan didesinfeksi menggunakan natrium hipoklorit 3\% selama 3 menit kemudian dicuci dengan air suling 3 kali setiap 2 menit. Kemudian biji didesinfeksi dengan alkohol $70 \%$ selama 2 menit dan kemudian dicuci dengan air suling tiga kali dan setiap kali 2 menit. Air steril ditambahkan dengan perbandingan 1: 10 (1 gram biji, $10 \mathrm{ml}$ air), disimpan dalam gelap selama dua hari pada 25 C. Setelah dua hari, fase cair disaring dengan Whatman No. 1 kertas saring dan ekstrak saring yang diperoleh digunakan untuk sintesis nanopartikel. Seng nitrat sebanyak 0.0297 gr ditambahkan ke $50 \mathrm{cc}$ air suling, kemudian tambahkan air suling hingga volume akhir mencapai $100 \mathrm{ml}$. Seng nitrat digunakan pada konsentrasi $0.1,0.25$, $0.5,0.75$ dan $1 \mathrm{mM} .10 \mathrm{ml}$ ekstrak yang diperoleh ditambahkan ke $90 \mathrm{ml}$ seng nitrat dengan konsentrasi yang disebutkan secara terpisah. Campuran ekstrak dan seng nitrat diinkubasi pada suhu 70 C selama 2 jam dan dikalsinasi pada 300 (2 jam) untuk mendapatkan bubuk putih [11].

\section{HASIL DAN PEMBAHASAN}

Pada penelitian yang dilakukan oleh Nagarajan dkk (2013) sintesis ZnO NPs dilakukan menggunakan ekstrak rumput laut hijau Caulerpa peltata, ekstrak rumput laut merah Hypnea Valencia dan ekstrak rumput laut coklat Sargassum myriocystum. Hasil menunjukkan bahwa terjadi penyerapan intensif $\mathrm{ZnO}$ NPs pada gelombang ultraviolet $(300-500 \mathrm{~nm})$. Apabila keduanya dibandingkan, ekstrak rumput laut coklat S. myriocystum memiliki proses yang lebih cepat dan stabil dalam pembentukan ZnO NPs. Berdasarkan laporan Nagarajan dkk (2013), pada pH rendah (5-7) menunjukkan bahwa tidak adanya penyerapan. Namun demikian, terjadi agregasi yang cukup dominan sehingga $\mathrm{ZnO}$ NPs tampak besar. Pada $\mathrm{pH} 8$, puncak penyerapan teramati pada gelombang $365 \mathrm{~nm}$ yang menunjukkan reduksi total seng nitrat menjadi nanopartikel seng. Hal ini mengindikasikan $\mathrm{pH}$ yang lebih tinggi akan menyebabkan tingkat reduksi semakin tinggi.

Pada penelitian yang dilakukan oleh Houseinpour dkk (2017) sintesis ZnO NPs dilakukan menggunakan ekstrak daun Dittrichia graveolens dengan variasi konsentrasi ekstrak (25\% dan 75\%), variasi $\mathrm{pH}(4,6$, dan 8), dan dalam berbagai waktu sentrifugasi (40, 80 dan 120 menit). Semua sampel menunjukkan dua puncak serapan karakteristik tajam pada gelombang 285 dan $320 \mathrm{~nm}$ yang disebabkan oleh band gap intrinsik ZnO. Puncak absorbansi pada gelombang $285 \mathrm{~nm}$ menunjukkan adanya spektrum serapan impuritas $\mathrm{ZnO}$. $\mathrm{ZnO}$ memiliki absorbansi yang kuat pada panjang gelombang antara 310-385 $\mathrm{nm}$. Puncak absorbansi dari $\mathrm{ZnO}$ telah diamati terjadi pada gelombang $320 \mathrm{~nm}$. Pada $\mathrm{pH} 4$ puncak absorbansi lebih rendah dibandingkan dengan puncak absorbansi pada $\mathrm{pH}$ 8.

Pada penelitian yang dilakukan oleh Zare dkk (2017) sintesis ZnO NPs dilakukan menggunakan ekstrak biji Cuminum cyminum dengan variasi $\mathrm{pH}$ 5-9. $\mathrm{PH}$ diatur menggunakan $\mathrm{HCl}(0,1 \mathrm{M})$ dan $\mathrm{NaOH}(0,1) \mathrm{M}$. Zare dkk melaporkan bahwa pada $\mathrm{pH}$ asam dan sangat basa dapat mengganggu proses sintesis. Telah dilaporkan bahwa dalam $\mathrm{pH}$ asam, ekstrak tidak memiliki kemampuan untuk mensintesis nanopartikel. PH optimum untuk sintesis nanopartikel adalah 8. Ketika pH ditingkatkan lagi ke nilai yang lebih tinggi, maka penurunan tajam dalam puncak serapan akan terjadi.

\section{PENUTUP}

Dari ketiga penelitian diatas, ditemukan adanya pengaruh variasi $\mathrm{pH}$ terhadap absorbansi $\mathrm{ZnO}$ NPs. Ekstrak tanaman diketahui berfungsi sebagai reduktor. Pada $\mathrm{pH}$ yang lebih tinggi akan menyebabkan tingkat reduksi semakin tinggi, sehingga puncak penyerapan akan semakin tinggi pula. Namun, absorbansi dan ketajaman puncak akan melemah setelah mencapai pH tertentu. PH optimum untuk sintesis nanopartikel menggunakan ekstrak rumput laut coklat S. myriocystum, ekstrak daun Dittrichia graveolens dan ekstrak biji Cuminum cyminum adalah 8 . 


\section{UCAPAN TERIMAKASIH}

Terimakasih kepada pihak pemberi dana penelitian, kepada lembaga/orang yang membantu penelitian, kepada orang yang membantu dalam diskusi, dll. Ucapan terimakasih kepada Dr. Iwan Sugihartono, M. Si dan Dr. Isnaeni, M. Sc yang telah membimbing dan membantu dalam proses pembuatan jurnal ini. Semoga review jurnal ini berguna dan bermanfaat bagi pembaca. Mohon maaf apabila terdapat kesalahan dan kekurangan dalam penulisan review ini.

\section{REFERENSI}

[1] X. Wang, et al., "Zinc Oxide Nanoparticles Affect Biomass Accumulation and Photosynthesis in Arabidopsis," Original Research, 2016.

[2] J. Santhoshkumar, S. V. Kumar and S. Rajeshkumar, "Synthesis of zinc oxide nanoparticles using plant leaf extract against urinary tract infection pathogen," Resource-Efficient Technologies, pp. 459-465, 2017.

[3] K. H. Choi, et al., "Antioxidant Potential and Antibacterial Efficiency of Caffeic AcidFunctionalized ZnO Nanoparticles," Nanomaterials, vol. 7, no. 6, p. 148, 2017.

[4] H. Agarwal, S. V. Kumar and S. Rajeshkumar, "A review on green synthesis of zinc oxide nanoparticles - An eco-friendly approach," Resource-Efficient Technologies, pp. 406-413, 2017.

[5] S. K. W. Ningsih, U. K. Nizar and U. Novitria, "SINTESIS DAN KARAKTERISASI NANOPARTIKEL ZnO DOPED Cu2+ MELALUI METODA SOL-GEL," Eksakta, vol. 18 no. 2, pp. 39-40, Oktober 2017.

[6] R. Nurbayasari, N. Saridewi and Shofwatunnisa, "Biosynthesis and Characterization of ZnO Nanoparticles with Extract of Green Seaweed Caulerpa sp," Jurnal Perikanan Universitas Gadjah Mada: 17-28 ISSN: 0853-6384 eISSN: 2502-5066, vol. 19, no. 1, pp. 17-26, 2017.

[7] G. Rajakumar, et al., "Green approach for synthesis of zinc oxide nanoparticles from Andrographis paniculata leaf extract and evaluation of their antioxidant, anti-diabetic, and anti-inflammatory activities," Bioprocess Biosyst Eng, vol. 41, pp. 21-30, 2018.

[8] J. S. Rana, P. Khatri and P. Jamdagni, "Green synthesis of zinc oxide nanoparticles using flower extract of Nyctanthes arbor-tristis and their antifungal activity," Journal of King Saud University, pp. 1-7, 2016. 